\title{
PERANCANGAN REAKTOR BATCH UNTUK PEMISAHAN PERAK DARI LARUTAN BEKAS PENCUCIAN FILM RADIOGRAFI
}

\author{
Salman Yasir Fakhry Putra, Noor Anis Kundari, Kris Tri Basuki \\ STTN-BATAN, Yogyakarta, Indonesia, sttn@batan.ac.id
}

\begin{abstract}
ABSTRAK
PERANCANGAN REAKTOR BATCH UNTUK PEMISAHAN PERAK DARI LARUTAN BEKAS PENCUCIAN FILM RADIOGRAFI. Penelitian ini dilakukan untuk menentukan kinetika proses pelarutan dan desain reaktor batch. Fixer bekas menjadi masalah karena mengandung Ag yang termasuk logam berat dan digolongkan sebagai limbah B3. Namun, logam Ag tersebut juga mempunyai nilai ekonomis karena tergolong logam mulia. Oleh karena itu, dilakukan perancangan reaktor batch untuk mengurangi masalah limbah di lingkungan. Metode untuk menentukan konstanta kinetika pada proses pelarutan adalah melarutkan $\mathrm{Ag}_{2} \mathrm{~S}$ dan $\mathrm{HNO}_{3}$, yang kemudian diaduk dan dipanaskan pada suhu $90^{\circ} \mathrm{C}$ konstan dengan memvariasikan waktu pengadukan. Nilai konstanta kinetika proses pelarutan adalah 0,216/menit. Berdasarkan nilai konstanta kinetika yang diperoleh, dapat dihitung rancangan reaktor batch pada proses pertukaran logam untuk kapasitas 99 l/bulan, yakni $\mathrm{D}=45 \mathrm{~cm}, \mathrm{H}=68 \mathrm{~cm}, \mathrm{t}=0,35 \mathrm{~cm}$, dan $\mathrm{P}=0,76$ watt. Adapun rancangan reaktor pada proses pelarutan adalah $\mathrm{D}=44 \mathrm{~cm}, \mathrm{H}=66 \mathrm{~cm}, \mathrm{t}=0,33 \mathrm{~cm}$, dan $\mathrm{P}=42,29$ watt.
\end{abstract}

Kata kunci: reaktor batch, fixer, pelarutan, kinetika, perancangan

\begin{abstract}
BATCH REACTOR DESIGN FOR SILVER RECOVERY FROM USED PHOTOGRAPHIC FIXER SOLUTION. This study was conducted to determine the kinetics of dissolution process and batch reactor design. Used photographic fixer solution contains silver which is considered hazardous materials. However, silver is also a precious metal. In this work a batch reactor was designed to recover silver from used fixer solution. The method for determining the kinetics constant of the dissolution process is by dissolving $\mathrm{Ag}_{2} \mathrm{~S}$ and $\mathrm{HNO}_{3}$. The solution was stirred and heated at a constant temperature of $90^{\circ} \mathrm{C}$ by varying the stirring time. The kinetics constant value was 0,216/min. Based on this constant value, batch reactor design for metal exchange process of $99 \mathrm{l} / \mathrm{month}$ could be calculated as follows $D=45 \mathrm{~cm}, H=68 \mathrm{~cm}, t=0,35 \mathrm{~cm}, P=0,76$ watts, and for dissolution process $D=44 \mathrm{~cm}, H=66 \mathrm{~cm}, t=0,33 \mathrm{~cm}, P=42,29$ watts.
\end{abstract}

Keywords:batch reactor, fixer, dissolution, kinetics, design

\section{PENDAHULUAN}

Fixer bekas menjadi masalah karena pada fixer bekas terkandung logam Ag dan fixer bekas tergolong limbah B3. Namun logam Ag yang terkandung pada fixer bekas juga mempunyai nilai ekonomis karena tergolong logam mulia. Berbagai teknologi digunakan untuk mendapatkan kembali Ag dari limbah larutan fixer yang kebanyakan efektif pada batas konsentrasi Ag tertentu. Perak dalam bentuk kompleks anionik tiosulfat $\left(\mathrm{Ag}\left(\mathrm{S}_{2} \mathrm{O}_{3}\right)_{2}\right)^{3-}$ dapat dipisahkan dari larutannya dengan cara elektrolisis, pertukaran logam (metallic replacement), pengendapan, penukar ion, membran cair emulsi (ELM), dan adsorbsi dengan kitin [1].

Reaksi pertukaran logam tunggal pada pemungutan perak dalam limbah larutan fixer logam $\mathrm{Mg}$ menggeser logam $\mathrm{Ag}$ pada $\mathrm{Ag}_{2} \mathrm{~S}_{2} \mathrm{O}_{3}$ dan membentuk $\operatorname{Ag}_{2} \mathrm{~S}$. Hal ini dikarenakan logam $\mathrm{Mg}$ lebih reaktif daripada logam $\mathrm{Ag}$ sehingga terjadi reaksi redoks. Selanjutnya, dilakukan reaksi pelarutan dengan cara melarutkan $\mathrm{Ag}_{2} \mathrm{~S}$ dengan $\mathrm{HNO}_{3}$ sehingga membentuk $\mathrm{AgNO}_{3}$.

Penelitian ini dilakukan untuk merancang reaktor batch yang mampu memulihkan perak dari limbah larutan fixer sehingga tidak mencemari lingkungan. Selain itu, logam perak juga mempunyai nilai ekonomis. Pemulihan 
logam perak dilakukan dengan cara melewatkan larutan fixer bekas cucian film radiografi pada logam $\mathrm{Mg}$ dalam reaktor. Pada saat terjadi kontak larutan fixer dengan logam, akan terjadi reaksi pertukaran logam $\mathrm{Mg}$ sehingga menghasilkan logam perak dan larutan $\mathrm{MgS}_{2} \mathrm{O}_{3}$. Selanjutnya, dilakukan proses pelarutan dengan menggunakan $\mathrm{HNO}_{3}$ sehingga terbentuk $\mathrm{AgNO}_{3}$.

Perancangan alat yang sesuai untuk memaksimalkan pemungutan perak dari limbah larutan fixer adalah perancangan reaktor batch. Penentuan desain reaktor batch menggunakan persamaan sebagai berikut [2].

$F a 0-F a+r a \int_{0}^{V} d V=\frac{d N a}{d t}$

Karena pada batch $\mathrm{FaO}=\mathrm{Fa}=0$, maka

$r a \int_{0}^{V} d V=\frac{d N a}{d t}$

$r a=\frac{d C a}{d t}=-k C a^{n}$

$-k C a^{n} \int_{0}^{V} d V=\frac{d N a}{d t}$

Untuk merancang reaktor batch, diperlukan persamaan kinetika. Pada pengolahan limbah fixer telah tersedia data kinetika pada proses pertukaran logam $\mathrm{Mg}$ [3], sementara dalam proses pelarutan belum tersedia. Oleh karena itu, dalam penelitian ini akan ditentukan terlebih dulu persamaan kinetika pada proses pelarutan.

Hasil penelitian ini diharapkan bisa menentukan persamaan kinetika pada proses pelarutan dan perancangan reaktor batch untuk pemisahan perak dari larutan bekas pencucian film radiografi.

\section{LANDASAN TEORI}

\section{Proses Pertukaran Logam Mg}

Reaksi pertukaran logam tunggal adalah perubahan kimia yang terjadi ketika sebuah unsur yang lebih reaktif menggantikan unsur yang kurang reaktif dari suatu senyawa. Reaktivitas logam dapat diketahui dari urutan pada deret volta. Pada deret volta, logam yang berada di sebelah kiri hidrogen $(\mathrm{H})$ tergolong logam yang reaktif, dan semakin ke kiri semakin reaktif. Sebaliknya, logam yang berada di sebelah kanan hidrogen adalah logam-logam yang kurang reaktif dan semakin ke kanan semakin kurang reaktif. Pada reaksi pertukaran logam tunggal yang terjadi pada proses pemungutan perak, logam $\mathrm{Mg}$ akan menggeser $\mathrm{Ag}$ yang terdapat dalam senyawa kompleks $\mathrm{Ag}_{2} \mathrm{~S}_{2} \mathrm{O}_{3}$. Pergeseran logam yang terjadi dapat dilihat pada reaksi berikut.

$\mathrm{Ag}_{2} \mathrm{~S}_{2} \mathrm{O}_{3}+\mathrm{Mg} \rightarrow \mathrm{Ag}_{2} \mathrm{~S}+\mathrm{MgS}_{2} \mathrm{O}_{3}+\mathrm{SO}_{3}$

Berdasarkan Reaksi (5) dapat diamati bahwa logam $\mathrm{Mg}$ menggeser posisi $\mathrm{Ag}$ yang menjadi atom inti dan berikatan dengan ligan $\mathrm{S}_{2} \mathrm{O}_{3}{ }^{-}$sehingga logam $\mathrm{Mg}$ menjadi atom inti dan berikatan dengan ligan $\mathrm{S}_{2} \mathrm{O}_{3}^{-}$menjadi $\mathrm{MgS}_{2} \mathrm{O}_{3}$. Ketika kompleks $\mathrm{Ag}_{2} \mathrm{~S}_{2} \mathrm{O}_{3}$ melalui proses pemungutan, kompleks akan terkonversi menjadi $\mathrm{Ag}_{2} \mathrm{~S}$.

\section{Proses Pelarutan Menggunakan $\mathrm{HNO}_{3}$}

Untuk mendapatkan perak murni, $\mathrm{Ag}_{2} \mathrm{~S}$ dilarutkan dengan asam nitrat $\left(\mathrm{HNO}_{3}\right)$ sehingga reaksinya akan menjadi seperti berikut.

$3 \mathrm{Ag}_{2} \mathrm{~S}+8 \mathrm{HNO}_{3} \rightarrow 6 \mathrm{AgNO}_{3}+2 \mathrm{NO}+3 \mathrm{~S}_{4} \mathrm{H}_{2} \mathrm{O}(6)$

Penentuan nilai konstanta kinetika (k) pada proses pelarutan dengan orde 1 yang diperoleh dari percobaan di laboratorium menggunakan persamaan sebagai berikut [2]:

$\ln (1-X)=-k . t$

Berdasarkan konstanta kinetika (k) dengan reaksi orde 2 , dapat ditentukan persamaan sebagai berikut [2]:

$\frac{1}{C a}-\frac{1}{C a_{0}}=-k . t$

$\mathrm{Ag}$ larut dan membentuk ikatan senyawa dengan NO menjadi $\mathrm{AgNO}_{3}$, kemudian dimurnikan dengan reaksi pertukaran logam tunggal menggunakan logam tembaga $(\mathrm{Cu})$ sehingga didapatkan logam Ag murni. Reaksi yang terjadi dapat dituliskan sebagai berikut:

$$
\mathrm{AgNO}_{3}+\mathrm{Cu} \rightarrow \mathrm{Ag}+\mathrm{Cu}\left(\mathrm{NO}_{3}\right)_{2}
$$

Logam Ag mengendap dan dipisahkan dengan $\mathrm{Cu}\left(\mathrm{NO}_{3}\right)_{2}$ sehingga didapatkan logam Ag murni yang siap untuk dilebur.

\section{Perhitungan Desain Reaktor Batch}

Reaktor batch tidak memiliki aliran masuk maupun aliran keluar reaktan atau produk ketika reaksi sedang berlangsung. Jadi, $\mathrm{Fj} 0=$ $\mathrm{Fj}=0$; menghasilkan keseimbangan mol umum pada spesies $j$, yang dinyatakan dengan persamaan berikut [2]:

$-k C j^{n} \int_{0}^{V} d V=\frac{d N j}{d t}$

Untuk sistem batch, di mana volume bervariasi ketika reaksi berjalan, volume 
biasanya dapat dinyatakan sebagai fungsi waktu atau konversi, baik untuk reaktor adiabatik atau isotermal. Karena itu, variabel persamaan diferensial dapat dipisahkan dalam salah satu cara berikut [2].

$V d t=N_{A 0} \frac{d X}{-r_{A}}$

atau

$d t=N_{A 0} \frac{d X}{-r_{A} V}$

Namun, untuk reaktor batch pada umumnya volume tidak ditentukan sebelumnya sebagai fungsi waktu. Maka, waktu $t$ yang diperlukan untuk mencapai konversi $\mathrm{X}$ adalah [2] :

$t=N_{A 0} \int_{0}^{X(t)} \frac{d X}{-r_{A} V}$

Dengan mengikuti reaksi di bawah ini [4]:

$A+\cdots \rightarrow v_{C} C+\cdots v_{N} N$

Reaksi dalam reaktor batch dengan volume V secara terus-menerus, untuk menentukan tingkat produksi, harus memperhitungkan waktu reaksi ( $t$ dalam Persamaan 13) dan down-time (td) antara batch. Total waktu per batch atau waktu siklus adalah [4].

$t_{c}=t+t_{d}$

Volume reaktor $(\mathrm{V})$ terkait dengan $\mathrm{N}_{\mathrm{A} 0}$, melalui persamaan keadaan (1) atau (9), harus ditentukan atau dianggap sebagai parameter [4]:

$V=\frac{\left(t+t_{d}\right) \operatorname{Pr}(C)}{v_{C} C_{A 0} \cdot X_{A}}$

Penentuan dimensi reaktor batch dilakukan dengan asumsi bahwa reaktor batch berbentuk silinder dan dengan mengikuti persamaan berikut [5]:

$V=\frac{1}{4} \pi D^{2} H$

Rasio antara diameter dan tinggi reaktor batch ditunjukkan pada persamaan berikut [5]:

$\frac{H}{D}=1,5$

$H=1,5 D$

Dengan mensubstitusi Persamaan (18) ke (19), maka diperoleh persamaan berikut:

$D=\sqrt[3]{\frac{4}{1,5}\left[\frac{V}{\pi}\right]}$
Untuk merancang pengaduk pada bejana atau tangki, ada banyak pilihan untuk jenis dan lokasi impeller, ukuran bejana atau tangki, jumlah dan ukuran baffle, dan sebagainya. Maka, perancangan unit pengaduk beserta impeller akan ditunjukan pada Gambar 1.

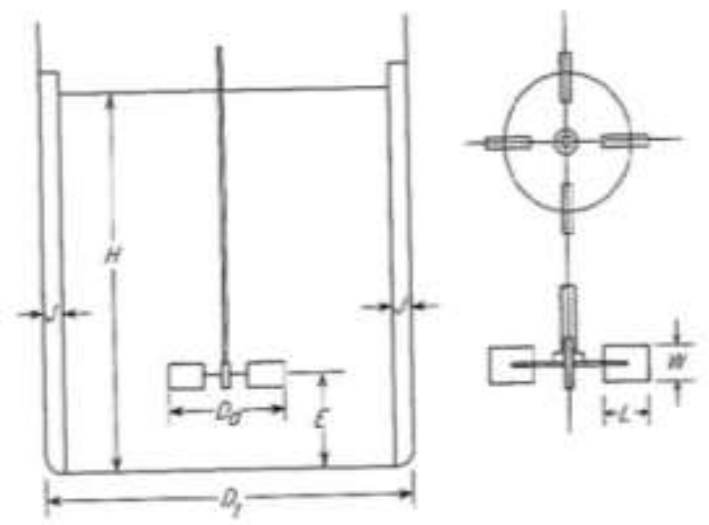

Gambar 1. Desain Pengaduk Jenis Turbulen [6]

$\frac{D_{a}}{D}=\frac{1}{3}$

$\frac{H}{D}=1$

$\frac{J}{D}=\frac{1}{12}$

$\frac{E}{D}=\frac{1}{3}$

$\frac{W}{D_{a}}=\frac{1}{5}$

$\frac{L}{D_{a}}=\frac{1}{4}$

Unit pengaduk membutuhkan sejumlah daya. Dalam tangki baffled dengan bilangan reynolds mendekati 10.000, jumlah daya independen dari bilangan reynolds dan viskositas bukan faktor. Dalam rentang ini, aliran sepenuhnya turbulen [6].

$N_{p}=K_{T}$

Ini akan menjadi

$P=\frac{K_{T} n^{3} D_{a}{ }^{5} \rho}{g_{c}}$

Dalam sistem pengadukan, kecepatan pengadukan sangat mempengaruhi efisiensi laju reaksi. Berdasarkan Persamaan (28), kecepatan pengadukan juga dipengaruhi oleh WELH (Water Equivalent Liquid Height) [7].

$\frac{W E L H}{2 \cdot D_{a}}=\left(\frac{n \cdot D_{a}}{600}\right)^{2}$

dengan 
$W E L H=H \cdot \frac{\rho \text { Fluida }}{\rho \text { Air }}$

Ketebalan reaktor batch dapat ditentukan berdasarkan persamaan sebagai berikut [8]:

$P_{\text {Design }}=(1-1,2) \cdot P_{\text {Operasi }}$

$t s=\frac{P \cdot R}{f \cdot E-0,6 P}+C$

Tutup reaktor sangat bermacam-macam, namun tutup yang sering dijumpai di reaktor kimia berjenis flanged and shallow dishead.

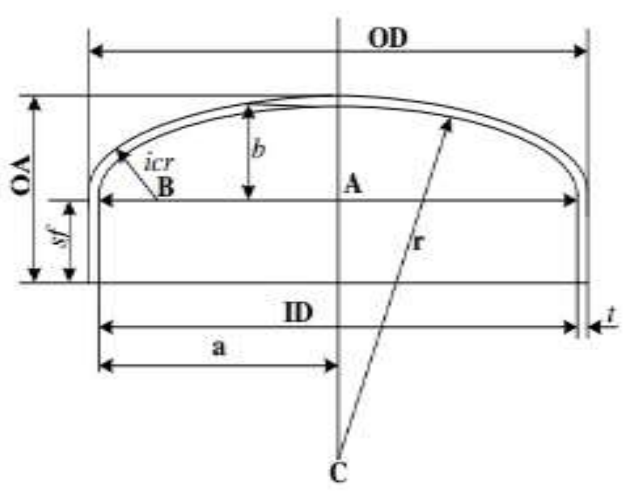

Gambar 2. Flanged and Shallow Dishead Reactor [8].

Penentuan tebal penutup mengikuti persamaan berikut [8]:

$t h=\frac{P \cdot R \cdot w}{2 \cdot f \cdot E-0,2 P}+C$

sehingga

Tinggi penutup $=$ th $+b+s f$

\section{METODOLOGI PENELITIAN}

\section{Bahan dan Alat Penelitian}

\section{Bahan Penelitian}

Bahan yang digunakan dalam perancangan reaktor batch untuk pemisahan perak dari limbah bekas film radiografi adalah limbah fixer yang berasal dari rumah sakit wilayah Yogyakarta, dengan konsentrasi 57,51 g/l. Bahan-bahan lainnya diperoleh dari Laboratorium Kimia Dasar STTN-BATAN Yogyakarta, yakni akuades, logam magnesium berbentuk pita dengan lebar $0,5 \mathrm{~cm}$ dan panjang $100 \mathrm{~cm}$, dan asam nitrat dengan konsentrasi $65 \%$ dan massa jenis $1,62 \mathrm{~kg} / 1$.

\section{Alat Penelitian}

Dalam perancangan reaktor batch untuk pemisahan perak dari limbah bekas film radiografi digunakan alat-alat: hot plate, magnetic stirrer, termometer, neraca analitik, kertas saring Whatman 42, oven, stopwatch, AAS, dan peralatan-peralatan kaca lainnya.

\section{Prosedur Penelitian}

Pengendapan $\mathrm{Ag}_{2} \mathrm{~S}$ dari $\mathrm{Ag}_{2} \mathrm{~S}_{2} \mathrm{O}_{3}$ dengan Menggunakan Logam $\mathrm{Mg}$

Proses pengendapan $\mathrm{Ag}_{2} \mathrm{~S}$ dilakukan dengan mereaksikan limbah larutan fixer dari rumah sakit dengan logam magnesium. Mula-mula diambil limbah larutan fixer sebanyak $500 \mathrm{ml}$ dan ditempatkan dalam gelas beker $500 \mathrm{ml}$. Kemudian ditimbang logam magnesium seberat 1 gram. Logam magnesium selanjutnya dimasukkan ke dalam limbah larutan fixer dan diaduk menggunakan pengaduk magnet. Endapan hasil reaksi disaring menggunakan kertas saring Whatman 42, lalu dikeringkan menggunakan oven sampai berat konstan.

\section{Penentuan Nilai Konstanta Kinetika $(k)$ Pelarutan $\mathrm{Ag}_{2} \mathrm{~S}$ Menggunakan $\mathrm{HNO}_{3}$}

Nilai konstanta kinetika (k) pada proses pelarutan ditentukan dengan melarutkan $\mathrm{Ag}_{2} \mathrm{~S}$ menggunakan $\mathrm{HNO}_{3}$ dengan konsentrasi yang sesuai perhitungan stoikiometri dan dipanaskan pada suhu konstan $90^{\circ} \mathrm{C}$. Endapan dan filtrat hasil reaksi dipisahkan menggunakan kertas saring Whatman 42. Langkah tersebut diulangi dengan melakukan variasi waktu pengadukan. Hasil pelarutan yang berupa filtrat kemudian dianalisis menggunakan spektrometri serapan atom.

\section{Perancangan dan Desain Reaktor Batch}

Prosedur perancangan dan desain reaktor batch adalah langkah pertama membuat diagram alir proses. Langkah berikutnya adalah menghitung neraca massa proses. Setelah menghitung neraca massa dengan kapasitas yang telah ditentukan, kemudian menentukan spesifikasi alat yang digunakan (pompa, pipa, jenis bahan yang digunakan untuk reaktor, dan lain-lain). Langkah selanjutnya adalah menghitung waktu pengadukan dalam reaktor, lalu menghitung volume beserta dimensi keseluruhan reaktor batch.

\section{HASIL DAN PEMBAHASAN}

\section{Penentuan Nilai Konstanta Kinetika Reaksi} (k) Pelarutan $\mathrm{Ag}_{2} \mathrm{~S}$ Menggunakan $\mathrm{HNO}_{3}$

Pada penelitian ini dilakukan pengamatan laju reaksi pada proses pelarutan $\mathrm{Ag}_{2} \mathrm{~S}$ dan $\mathrm{HNO}_{3}$ 
dengan kondisi pengamatan di laboraturium dan perhitungan sesuai stoikiometri. Endapan $\mathrm{Ag}_{2} \mathrm{~S}$ dilarutkan dengan $\mathrm{HNO}_{3}$ sehingga membentuk $\mathrm{AgNO}_{3}$, dengan suhu tetap dijaga konstan sebesar $90^{\circ}$ Celcius. Untuk menentukan kinetika pada proses pelarutan maka dilakukan variasi waktu pengadukan, yaitu 15, 20, 35 50, 70, dan 80 menit. Setelah dilakukan variasi tersebut, diperoleh konsentrasi hasil spektrometri serapan atom seperti ditunjukkan pada Tabel 1.

Tabel 1. Hasil Spektrometri Serapan Atom

\begin{tabular}{cc}
\hline $\begin{array}{c}\text { Waktu } \\
\text { (menit) }\end{array}$ & Konsentrasi (Ca) (ppm) \\
\hline 15 & 2,1098 \\
20 & 2,0641 \\
35 & 1,0959 \\
50 & 2,6999 \\
70 & 4,9978 \\
80 & 13,1715 \\
\hline
\end{tabular}

Berdasarkan hasil spektrometri serapan atom dihitung konversi yang terjadi selama proses pelarutan dalam variasi waktu. Perhitungan konversi ini ditunjukkan pada Tabel 2.

Tabel 2. Perhitungan Konversi

\begin{tabular}{cc}
\hline Waktu (menit) & Konversi (X) \\
\hline 15 & 0,989451 \\
20 & 0,989680 \\
35 & 0,994521 \\
50 & 0,986501 \\
70 & 0,975011 \\
80 & 0,934143 \\
\hline
\end{tabular}

Dari Tabel 2 dapat dibuat grafik hubungan antara konversi dan waktu, untuk menentukan konstanta kinetika. Untuk reaksi order 1, grafik hubungan antara konversi dan waktu pengadukan ditunjukkan dalam Gambar 3 .

Gambar 4 menunjukkan bahwa untuk reaksi orde 2, diperoleh nilai konstanta kinetika sebesar 0,0007/C.s dengan Nilai $\mathrm{R}^{2}$ sebesar 0,4587 .

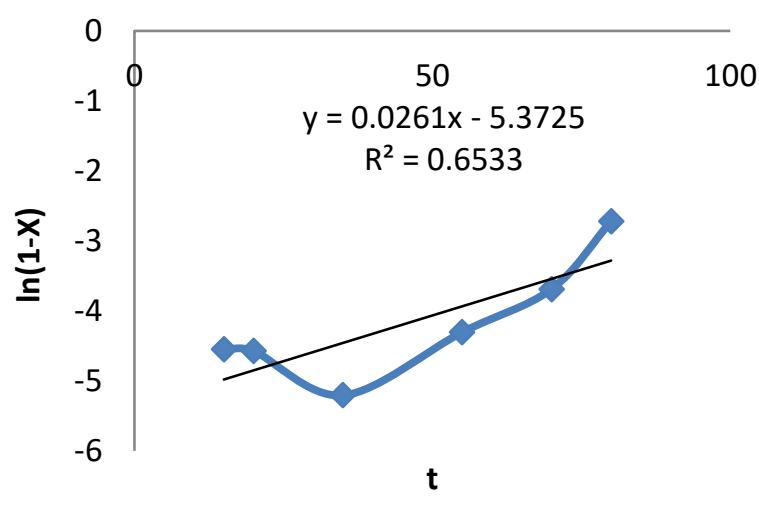

Gambar 3. Hubungan konversi dengan waktu pengadukan.

Hasil penelitian menunjukkan bahwa untuk proses pelarutan diperoleh nilai konstanta kinetika sebesar 0,0261/menit dengan $\mathrm{R}^{2}$ sebesar 0,6533 .

Untuk menentukan nilai konstanta kinetika pada reaksi orde 2, akan ditunjukkan pada Gambar 4 berikut ini.

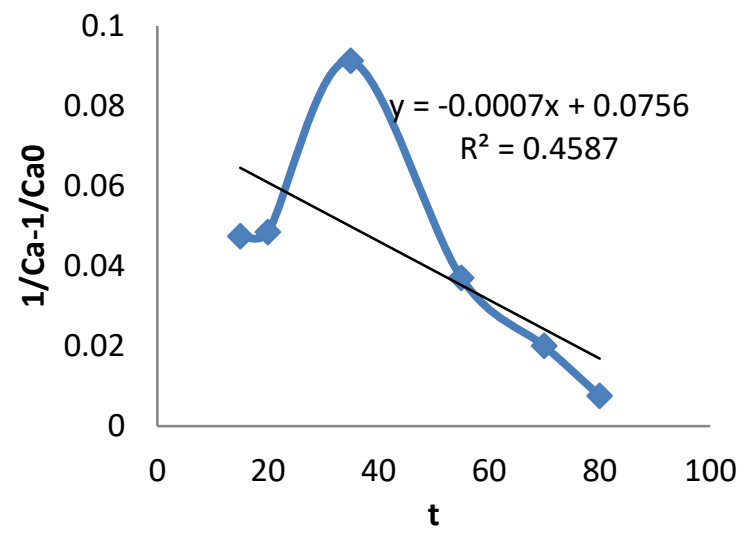

Gambar 4. Hubungan Konsentrasi terhadap Waktu Reaksi Orde 2

Jika dibandingkan hasil antara reaksi orde 1 dan orde 2 maka hasil yang lebih baik terdapat pada orde 1 karena nilai $\mathrm{R}^{2}$ pada orde 1 lebih besar dibandingkan dengan nilai $R^{2}$ pada orde 2. Oleh karena itu, perancangan dan desain reaktor batch akan menggunakan nilai konstanta kinetika pada reaksi orde 1 . 


\section{PERANCANGAN REAKTOR BATCH}

\section{Diagram Alir Proses}

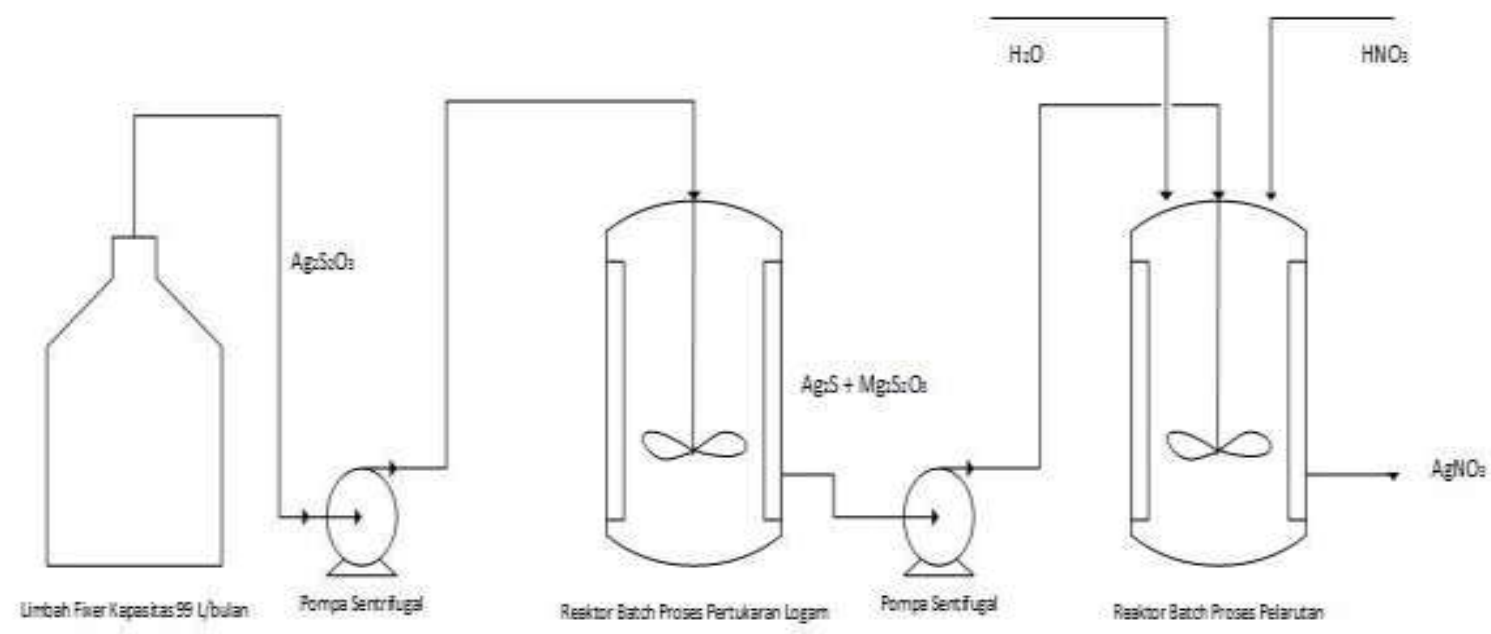

Gambar 5. Diagram Alir Proses Reaksi Pertukaran Logam dan Pelarutan

Berdasarkan Gambar 5, limbah fixer dipompa menggunakan pompa sentrifugal kemudian masuk ke reaktor untuk proses pertukaran logam menggunakan magnesium. Proses pertukaran logam terjadi dan membentuk $\mathrm{Ag}_{2} \mathrm{~S}$ dan $\mathrm{Mg}_{2} \mathrm{~S}_{2} \mathrm{O}_{3}$ sebagai hasil reaksi yang sesuai dengan reaksi pada Persamaan (5). Setelah proses pertukaran logam berlangsung, selanjutnya hasil proses dipompa dan masuk reaktor selanjutnya.
Pada proses tersebut merupakan proses pelarutan menggunakan $\mathrm{HNO}_{3}$ sebagai pelarut. Selanjutnya, $\mathrm{HNO}_{3}$ melarutkan $\mathrm{Ag}_{2} \mathrm{~S}$ dan membentuk $\mathrm{AgNO}_{3}$ yang sesuai dengan reaksi pada Persamaan (6).

\section{Desain Reaktor Batch Proses Pertukaran Logam}
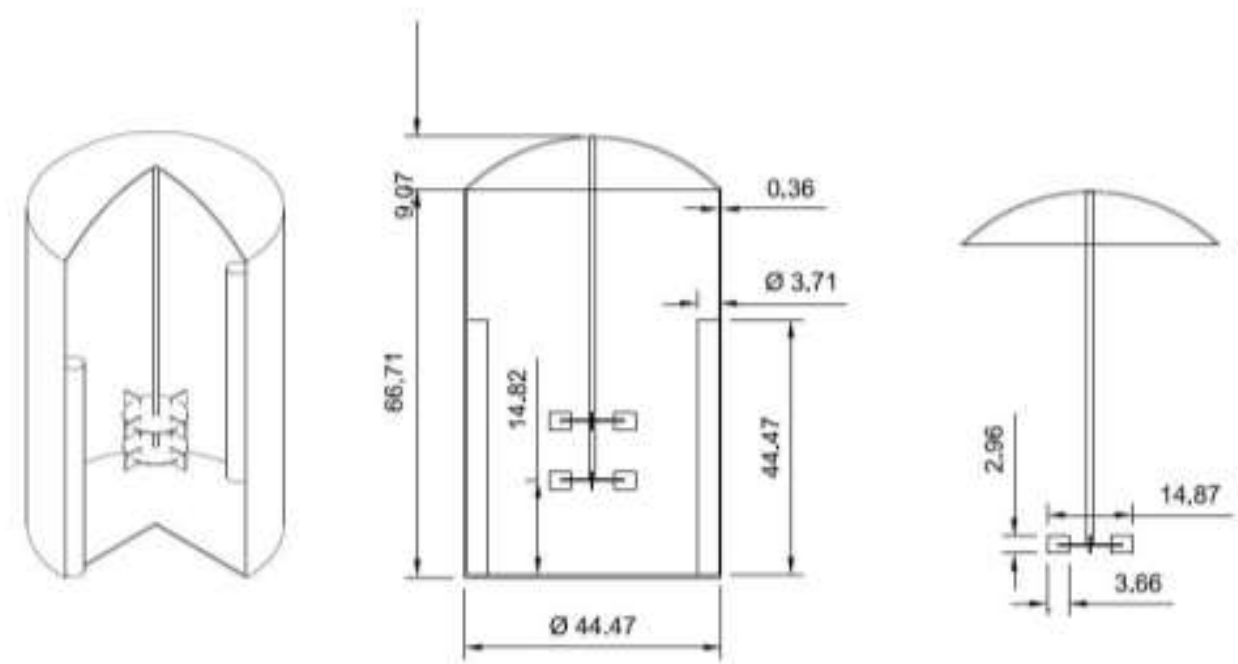

Gambar 6. Reaktor Batch Proses Pertukaran Logam 


\section{Desain Reaktor Batch Proses Pelarutan}
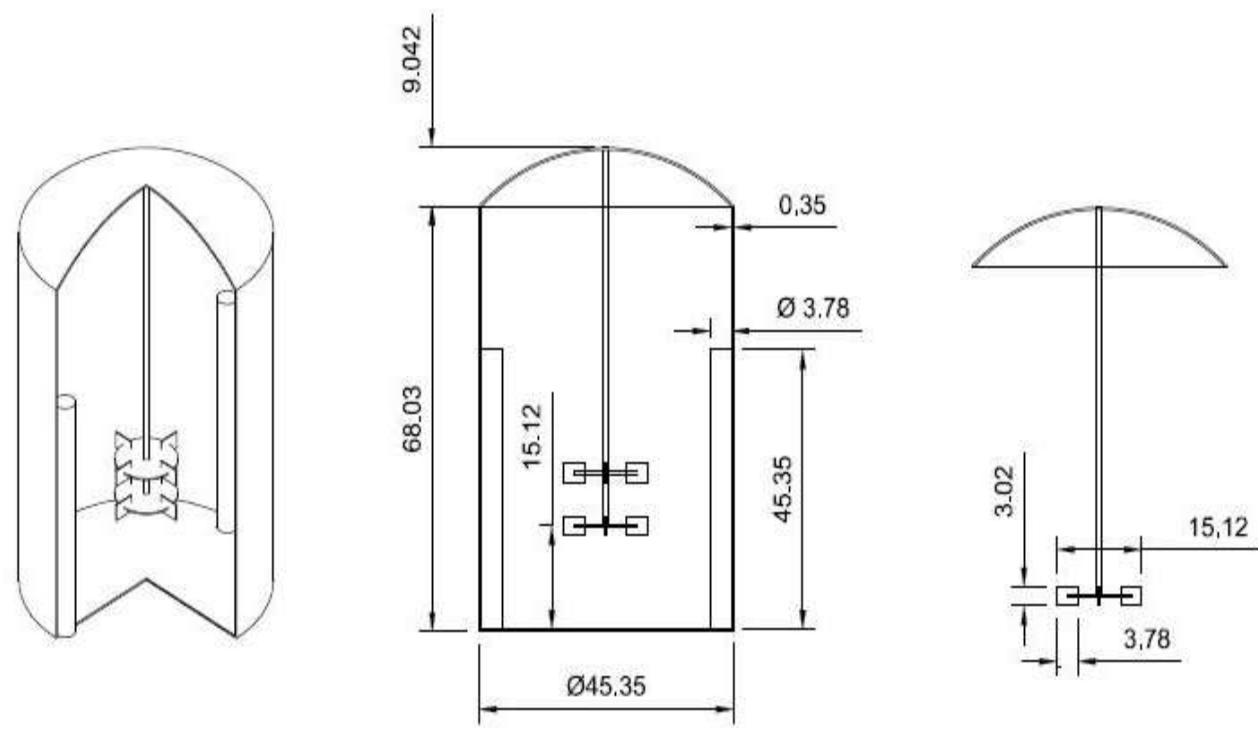

Gambar 7. Reaktor Batch Proses Pelarutan

\section{KESIMPULAN}

Berdasarkan data yang diperoleh dari spektrometri serapan atom (AAS), konstanta kinetika reaksi pada proses pelarutan adalah $0,0261 /$ menit untuk reaksi orde 1 dan 0,0007/C.menit untuk reaksi orde 2.

Dimensi reaktor batch untuk proses reaksi pertukaran logam dan pelarutan dapat dihitung. Hasil perhitungan dimensi yang diperoleh adalah sebagai berikut.

a. Reaktor batch proses reaksi pertukaran logam:

Volume $=0,1287 \mathrm{~m}^{3}$

Diameter $=0,45 \mathrm{~m}$

Tinggi $=0,68 \mathrm{~m}$

Tebal shell $=0,0035 \mathrm{~m}$

Tebal head $=0,0033 \mathrm{~m}$

Tinggi head $=0,0942 \mathrm{~m}$

Daya yang dikonsumsi $=0,76$ watt

Kecepatan pengadukan $=16,35 \mathrm{rpm}$

b. Reaktor batch proses pelarutan:

Volume $=0,101 \mathrm{~m}^{3}$

Diameter $=0,44 \mathrm{~m}$

Tinggi $=0,66 \mathrm{~m}$

Tebal shell $=0,0036 \mathrm{~m}$

Tebal head $=0,0033 \mathrm{~m}$

Tinggi head $=0,0072 \mathrm{~m}$

Daya yang dikonsumsi $=42,29$ watt

Kecepatan pengadukan $=20,28 \mathrm{rpm}$

\section{SARAN}

1. Hasil perancangan ini diharapkan dapat dilanjutkan ke tahap selanjutnya, yaitu rancang bangun alat dan dapat digunakan pada fasilitas pengolahan film radiografi.

2. Perlu dilakukan penelitian lagi yang terkait dengan perancangan reaktor dan pemilihan bahan agar lebih efisien dan optimal.

3. Pada proses pelarutan perlu dilakukan penelitian lebih lanjut dikarenakan variasi waktu yang dilakukan hanya sampai maksimal 80 menit sehingga kinetika yang diperoleh masih kurang optimal.

\section{DAFTAR PUSTAKA}

1. Songkroah, C., C. Nakbanpote, and P. Thiravetyan, 2003. "Recovery of SilverThiosulphate Complexes with Chitin" in: Process Biochemistry Journal, 39, 15531559.

2. Fogler, H. Scot, 2004. Solutions Manual for Elements of Chemical Reaction Engineering. Third Edition. Ann Arbor: The University of Michigan.

3. Perkasa, P.D.C, 2015. Pemungutan Perak dari Larutan Fixer Pencuci Film Radiografi Berbasis Reaksi Pertukaran Logam. STTN-BATAN Yogyakarta.

4. Missen, R.W., C.A. Mims, B.A. Savilley, 1999. Introduction to Chemical Reaction 
Engineering and Kinetics. United State of America: John Willey and Sons, Inc.

5. Silla, Harry, 2003. Chemical Process Engineering Design and Economics. New Jersey, USA: Stevens Institute of Technology Hoboken.

6. McCabe, W.L., C.J. Smith, P. Harriott, 1993. Unit Operations of Chemical Engineering. USA: McGraw-Hill, Inc.

7. Rase, H.F., 1977. Chemical Reactor Design for Process Plants. 2 Volumes, (Willeys).

8. Brownell, L.E. and E.H. Young, 1979. Process Equipment Design. New York: John Willey and Sons, Inc.

9. Suryati, Linda, 2003. "Pengambilan Kembali Perak Buangan Berdasarkan
Metode Reduksi Kimiawi." Penelitian Dosen Muda. Semarang: UNDIP.

10. Sardjono, I.D., Prayitno, H. Poernomo, W. Yuwono, 2006. Pemakaian Metode Adsorpsi Gelembung untuk Pemungutan Kembali Unsur Ag dari Air Limbah Cucian Film Fotothoraks. Yogyakarta: Pusat Teknologi Akselerator dan Proses Bahan-BATAN.

11. Kuswati, Hari, D. Handoyo, I. Kohar, 2010. Perolehan Kembali Logam Perak dari Limbah Cair Pencucian Film Studio Dibanding Film X-Ray dengan Menggunakan Metode SN Flake. Surabaya: Universitas Surabaya. 